\title{
BROWN v. BOARD OF EDUCATION: RELIVING AND LEARNING FROM OUR RACIAL HISTORY
}

\author{
Derrick Bell*
}

In the midst of a fierce battle, soldiers, fighting in what they consider a great cause, seek encouragement in their struggles. They do not welcome criticism and reject out-of-hand even well-intended warnings that their cause is doomed to failure. By 1970, there had been many court battles, but finally school desegregation advocates were beginning to make some advances in their efforts to gain implementation of the Supreme Court's decision invalidating racial segregation in the public schools. ${ }^{1}$

So, we were angered rather than enlightened when highly-respected Yale Law School professor, Alexander Bickel, wrote that while he did not wish:

to detract from the nobility of the Warren Court's aspiration in Brown, nor from the contribution to American life of the rule that the state may not coerce or enforce the separation of the races. But it is to say that Brown v. Board of Education, with emphasis on the education part of the title, may be headed for-dread word-irrelevance. ${ }^{2}$

Unfortunately, Bickel's prediction proved accurate. The Brown decision, while never overturned, has become irrelevant. Today, we find that despite literally hundreds of school desegregation suits, many lasting for decades, most black and Hispanic students attend public schools that are both racially separate and educationally ineffective. A study issued in early 2003 by the strongly pro-integration Harvard Civil Rights Project ${ }^{3}$ reports that as of the 2000-2001 school year, white students, on average, attend schools where eighty percent of the student body is white. Thus, the decision retains its symbolic value as a major exemplar of the country's highest ideals, but is of only marginal use in challenging the racial discrimination still deeply ingrained in the schools and so much of the society.

\footnotetext{
* Visiting Professor, New York University School of Law. This lecture utilizes material contained in Derrick Bell, Silent CovenAnts: BROWN V. BOARD OF EDUCATIONAND THE UNFUlFILlEd Hopes For RACIAL REFORM (2004).

1. See, e.g., Green v. County Sch. Bd., 391 U.S. 430 (1968).

2. Alexander Bickel, The Supreme Court and the Idea of Progress 150-51 (1970).

3. Erica Frankenberg et al., A Multiracial Society with Segregated Schools: Are We LOSING THE DREAM? (2003), available at http://www.civilrightsproject.harvard.edu/research/reseg03/ AreWeLosingtheDream.pdf (last visited Apr. 12, 2004).
} 
Is there a message discernible in the Brown decision's irrelevance? I think there is. In examining the rise and fall of what appeared to be the great civil rights policy breakthroughs of the Nineteenth and Twentieth Centuries, I find a predictable three-part pattern that, with little variation, repeats itself again and again. The Brown decision fits well within this pattern:

First, the interest of blacks in achieving racial equality is accommodated only when that interest converges with the interests of whites in policy-making positions. This convergence of interests is far more important to gaining relief than is the degree of harm suffered by blacks or the character of proof offered to prove this harm.

Second, even when interest convergence results in a potentially effective racial remedy, that remedy is abrogated at the point that policymakers fear the remedial policy is threatening the superior societal status of whites, particularly those in the middle and upper classes.

Third, the rights of blacks are always vulnerable, subject to be sacrificed, or used as catalysts enabling whites to settle serious policy differences. Major examples of this sword of Damocles danger include the compromises on slavery made by the Constitution's Framers, the Hayes-Tilden Compromise of 1877, the Southern Black Disenfranchisement Compromises of the late $1890 \mathrm{~s}$, and more recently, the undermining of hard-won rights to nondiscrimination under the equal protection clause.

By the application of these unacknowledged but quite viable principles, we can see more clearly the degree to which civil rights policy decisions resemble one another. For example, the Brown decision in 1954 is the twentieth century equivalent of the Emancipation Proclamation in the nineteenth. Both had symbolic value for black people, promising racial justice; and neither provided substantive government enforcement to eliminate the oppression blacks suffered - first from abject slavery and then from racial segregation. While separated by almost a century, Lincoln's famous executive order and the Supreme Court's landmark decision are remarkably similar both in their motivations and in their effects.

SIMILARITIES:

1. Blacks and white progressives looked to law to recognize racial injustice and provide a remedy for it;

2. Policymakers (Lincoln and the Supreme Court) saw political benefit in recognizing injustices and in responding when they did - after refusing to do so at earlier times;

3. Even though the policymakers' actions had real value for the country, they enraged a great many whites who deemed the recognition of racial bias against blacks as an abandonment of their superior status as whites. 
4. The benefits to blacks were more symbolic than real and when conditions changed, policymakers gave way to pressures of the still enraged whites - often leaving blacks in a worse position, or only marginally better than they were before.

Let's examine the two civil rights policies more closely:

\section{Emancipation Proclamation}

On January 1, 1863, President Lincoln, as he had warned the South three months earlier, issued an executive order called the Emancipation Proclamation. ${ }^{4}$ Black people and white abolitionists were jubilant. One black preacher who, with his congregation, had held an all-night watch meeting awaiting word that Lincoln had kept his word, reflected the feelings of the black community in an exuberant, if unrealistic welter of Biblical metaphor. "Sound the loud timbrel o'er Egypt's dark sea, Jehovah hath triumphed, his people are free."

The Proclamation that gladdened the hearts of black people enraged a great many northern whites. Lincoln was condemned for, in their thinking, transforming a bloody war to save the Union into a war to free the slaves. Less than a week after Lincoln signed a preliminary measure in September 1862, warning those in the Confederacy of what he would do if they did not rejoin the Union, the legislature in his home state of Illinois condemned the act as an action without any legal authority that contracted a war undertaken to preserve the union into a crusade to end slavery. The political backlash cost Lincoln's Republican Party heavily in the midterm elections of $1862{ }^{6}$

When Lincoln issued the Proclamation, it sparked protests throughout the North, some of them violent. Viewing black people, whether slave or free, as the cause of their distress, white rioters in New York City and other places killed and persecuted black people in uncounted numbers. ${ }^{7}$

\footnotetext{
4. Proclamation No. 17, 12 Stat. 1268 (Jan. 1, 1863).

5. Frederick Douglass, Life and Times of Frederick Douglass: His Early Life as a Slave, His Escape From Bondage, ANd His Complete History 353 (1962).

6. J.G. Randall, Constitutional Problems Under Lincoln 100 (rev. ed., Univ. of Ill. Press 1951) (1926). See also John Hope Fran klin \& Alfred A. Moss, Jr., From Slavery to Freedom: A History of African-Americans 230-33 (8th ed., Knopf 2000) (1947).

7. Lincoln's issuance of the Emancipation Proclamation in 1863, and the black-white responses to his action, were foreshadowed by abolition policies in the Northern states a half-century earlier. In the Northern states, slavery was abolished by a constitutional provision in Vermont (1777), Ohio (1802), Illinois (1818), and Indiana (1816); by a judicial decision in Massachusetts (1783); by constitutional
} 
Actually, as a legal matter, the Proclamation freed no slaves. Its terms were specifically limited to those areas still under the control of the Confederacy, and thus beyond the reach of federal law. Slaveholding territories which had sided with the Union were carefully excluded. But Lincoln's dramatic action had a symbolic effect that far exceeded its legal force. Blacks made no distinction between the areas covered by the Proclamation and those excluded from its impact.

Enslaved blacks did not revolt on a wholesale basis, but as word of the Emancipation filtered down to them, increasing numbers simply slipped away or became disloyal, particularly when Union troops approached.

The real motivation for Lincoln's action, as his advisors had predicted, was that the Emancipation Proclamation:

- disrupted the Southern work force;

- served to prevent France and England from entering the war on the side of the Confederacy, and;

- opened the way for the enlistment of blacks; by war's end more than 200,000 blacks

were serving in the Union Army.

As has so frequently been the case, the advantages to the Nation of an action nominally taken to benefit blacks were lost on the mass of working class whites.

Following a period of Reconstruction, which was poorly supported by the government, the racial issue was turned over to the former slaveholders and their political representatives. For the rest of the Nineteenth Century and well into the Twentieth, black individuals were exploited, harassed, and lynched. The conditions in which they lived, while not slavery, were hardly the freedom and citizenship for which they had hoped for so long.

\section{BROWN V. BOARD OF EDUCATION}

The pattern repeated itself on May 17, 1954, when the Court's Brown decision held that segregated schools were inherently unequal and, thus, unconstitutional. $^{8}$ Along with the black community across the country, the NAACP staff hailed the high Court's opinion with cheers, toasts, and impromptu dancing, but according to one report, Thurgood Marshall, one of

interpretation in New Hampshire; and by gradual abolition acts in Pennsylvania (1780), Rhode Island (1784), Connecticut (1784 and 1797), New York (1799 and 1817), and New Jersey (1804). Leon F. Litwack, North of Slavery: The Negro in the Free States, 1790-1860, at 3 n. 1 (1961).

8. Brown v. Bd. of Educ., 347 U.S. 483, 495 (1954). 
the chief architects of the litigation wandered, morosely, through the happy throng frowning: "You fools go ahead and have your fun," he said, "but we ain't begun to work yet." Marshall's admonition was prophetic.

While not mentioned in the opinion, the Brown decision was likely motivated by the need to counteract the reports of segregation and lynching that received international attention, particularly in the media dominated by communist governments. ${ }^{10}$ In its briefs to the Court, the Justice Department urged invalidating segregation as a means of improving America's image as the country competed with Russia to influence mainly non-white people emerging from colonialist domination. The decision also responded to the widespread fear of subversive activity at home exploited during the McCarthy era. Justice Felix Frankfurter, a member of the Brown Court, while concurring in one of the anti-communist cases of that era, observed that the Court "may take judicial notice that the communist doctrines which these defendants have conspired to advocate are in the ascendency in powerful nations who cannot be acquitted of unfriendliness to the institutions of this country." 11

Looking back to that time, it is likely that not since the Civil War had the need to remedy racial injustice been so firmly aligned with the country's vital interests at home and abroad. The historic attraction to granting recognition and promising reform of racial injustice when such action converges with the Nation's interests provided an unacknowledged motivation for the Court's ringing statement in Brown.

This statement provided a symbolic victory to petitioners and the class of blacks they represented, while, in fact, giving both a new, improved face to the Nation's foreign policy, and responding to charges of blatant racial bias at home.

As were their forebears when Lincoln issued the Emancipation Proclamation, southern whites were outraged by the Brown decision and, under leadership traditionally ready to use racism as an easy access to political power, formulated a massive resistance campaign.

A year later, the Court in Brown II, reacting to the cries of "never" coming from the South, and the absence of support from the executive and legislative branches, backed away from its earlier commitment, and issued a fall-back decision that enabled school desegregation with "all deliberate

9. Lerone Bennett, Jr., Confrontation: Black and White 221-22 (1965).

10. Mary L. Dudziak, Cold War Civil Rights: Race and the Image of American DemOCRACY 15, 26-27, 111-12 (2000).

11. Dennis v. United States, 341 U.S. 494, 547 (1951) (Frankfurter, J., concurring). 
speed," a standard so vague it set the stage for the Court's refusal to issue orders requiring any meaningful school desegregation for almost fifteen years. $^{12}$

Seeking to give substance to the ringing rhetoric in Brown, civil rights lawyers, including this author, fought hard to gain court orders requiring compliance with the Brown decision. Success in those cases led to the admission of black children to white schools, but seldom the reverse.

Black schools were closed - regardless of quality - by the hundreds and black teachers and administrators were fired by the thousands. We could win cases requiring racial balancing of schools and the busing of children, but we could not require whites to remain in the schools we had worked so hard to desegregate.

The great heavyweight boxing champion, Joe Louis, said of an opponent, "he can run but he can't hide." Whites, though, could run and hide their children in white schools, private or suburban, that court orders could not reach. After many years, the courts stopped trying. ${ }^{13}$

We should now see that agreements based on interest convergence and those sacrificing black rights in order to settle differences between contending white groups - what I call silent covenants - while differing so much in result, are two sides of the same coin. The two-sided coin with involuntary racial sacrifice on the one side, and interest-convergent remedies on the other can be called: "racial fortuity."

Racial fortuity resembles a contract law concept - the third-party beneficiary. In brief, two parties may contract to provide goods or services to a third-party. For example, a husband wishing to have flowers delivered to his wife on a weekly basis, contracts with a florist to provide this service. If the florist fails to do so, the husband can sue, but there is a large and complicated body of law as to when the wife can sue the florist. While she was the intended beneficiary, she was not a party to the contract and may not even have known about it. ${ }^{14}$

One aspect of this body of law is clear. The contracting parties must intend to confer a benefit on a third-party. As one court put it, "[t]he test is

12. Brown v. Bd. of Educ., 349 U.S. 294 (1955). (1974).

13. See, e.g., Bd. of Educ. v. Dowell, 498 U.S. 237 (1991); Milliken v. Bradley, 418 U.S. 717

14. See 13 Samule Williston \& Richard A. Lord, A Treatise on the Law of Contracts $\S 37: 1$ (4th ed. $1990 \&$ Supp. 2003). 
whether the benefit to the third person is direct to him or is but an incidental benefit to him arising from the contract. If direct, [the third party] may sue on the contract ...."15 Thus, in many states, the wife could sue the florist. If incidental, however, the third-party has no right of recovery.

Consider this hypothetical example. If Gotham Foods contracts with Ace Builder to build a new shopping center in the heart of an all-black area, Inner City, black residents may benefit from new job opportunities, better shopping at lower prices, and an increase in property values. Other businesses may be attracted to the area with similar benefits. Suppose, though, Ace Builder backs out of the contract. Gotham Foods can sue Ace Builder, but the residents of Inner City, as incidental beneficiaries, are simply out of luck. They will have no case that courts will recognize against either Gotham Foods or Ace Builder. This may be true even if some Inner City residents have taken actions and expended funds in the expectation that the shopping center would be built.

The law describes residents of Inner City as "incidental beneficiaries," those who a contract may have benefitted even though the contracting parties did not have them in mind. This is precisely the condition in which black people find themselves in racial policy-making. Given that they have often worked hard in seeking remedies for varying forms of discrimination, they are certainly interested in the contracting or policy-making process, but as far as the law is concerned, they are only "incidental," or fortuitous beneficiaries. That is, white policy-makers adopt racial policies that sacrifice black interests or recognize and provide relief for discrimination in accordance with their view of the fortuitous convergence of events.

Sometimes, as in my Gotham Developer/Ace Builder hypothetical, the parties are identifiable entities. Often though, there is no technical contract as such. Rather, policy-makers weigh various options and come to agreements or silent covenants. The Brown decision reflects the Supreme Court Justices' consensus that for reasons of foreign policy and domestic tranquility, constitutional protection for segregation must end. At the Constitutional Convention, agreements were reached that sacrificed the freedom hopes by blacks because the Framers concluded that they could not gain support for the Constitution unless it recognized slavery and protected slave owners' property in slaves.

15. E.g., Cherry v. Aetna Cas. \& Sur. Co., 21 N.E.2d 4, 7 (IIl. App. Ct. 1939) (quoting Carson Pirie Scott \& Co. v. Parrett, 178 N.E. 498, 501 (Ill. 1931)), aff'd, 25 N.E.2d 11 (Ill. 1939). 
As I have said, racial policy actions may be influenced, but are seldom determined, by the seriousness of the harm blacks are suffering, by the earnest petitions they have argued in courts, by the civil rights bills filed in legislative chambers, or even by impressive protests conducted in the streets. None of these change blacks' status as fortuitous beneficiaries. As with incidental beneficiaries in contract law, "[t]he test is whether the benefit to the third person is direct to him or is but an incidental benefit to him arising from the contract. If direct, he may sue on the contract; if incidental he has no right of recovery thereon." 16

But, aren't racial policies often justified by claims that they are intended to remedy discrimination? Didn't Lincoln's Emancipation Proclamation, by its very terms, claim to abolish slavery? Didn't the post-Civil War Amendments grant rights of citizenship to the former slaves? And didn't Brown v. Board grant the relief the NAACP lawyers sought by its finding that the Constitution cannot be read to countenance racial segregation in the public schools?

All true, but these commitments were made when those making them saw that they themselves could derive benefits - seldom openly discussed - that were at least as important as those blacks would receive. Blacks were not necessary parties to these commitments. Lincoln acted in an understanding with his generals and other supporters that if he abolished slavery, foreign governments would not enter the Civil War on the side of the Confederacy, and Union armies could enlist the freed slaves to fill their badly depleted ranks.

The post-Civil War Amendments were adopted with the understanding that by doing so, Republicans would maintain control of the federal government for years to come. And the Supreme Court was motivated to decide Brown as it did because it agreed with the State Department that invalidating segregation in the public schools would benefit the Nation's foreign policy. While blacks complained bitterly when each of these "civil rights" arrangements were not enforced because policy-makers moved on to new concerns, blacks were, as fortuitous beneficiaries, unable to gain meaningful enforcement despite their good faith expectation that commitments set out in the law, even in the Constitution, would be honored.

Thus, when the crisis of 1876 prompted the Hayes-Tilden Compromise, which withdrew Northern army forces, blacks, who had built communities across the south on constitutional and statutory commitments to protect them, 
found no relief for the destruction of their property or the wanton murder of their loved ones. And when the opposition to Brown gained far more strength than those who supported it, the Court backed away from the firm relief it had earlier promised. Despite the litigation of literally hundreds of school desegregation cases over decades, relatively few desegregated schools retained that status for very long. Both courts and the other branches of government, bowing to vigorous opposition, backed away from their initial commitments. As far as the law was concerned, blacks had been fortuitous beneficiaries.

While the economic, political, and psychic benefits whites gained from slavery, segregation, and simply their status as whites compared to blacks, are demonstrable, the real cost to whites of those benefits are unacknowledged. As with blacks, most whites are not directly involved in racial policy-making. This is true even though the racial policy-makers are usually white, and whites generally identify with them assuming their influence is pivotal-as, admittedly, it often is. But their preference, often their insistence, on laws that undermine black rights and provide legal standing to various forms of discrimination, do not ensure the maintenance of these discriminatory policies when conditions change. In this sense, whites too are fortuitous beneficiaries to racial policies.

Jim Crow laws that would eventually segregate blacks in every aspect of public life began to emerge out of a series of unofficial racial agreements between white elites and poorer whites who demanded laws segregating public facilities to ensure official recognition of their superior status over blacks with whom, save for color, they shared a similar economic plight.

Then in the late 1940s, policy-makers and the Supreme Court began to revoke support for segregation in its most blatant forms. President Truman, under pressure from civil rights groups, issued executive orders providing for "equal treatment and opportunity in the armed services," and abolishing "racial discrimination in federal employment." 17 The Supreme Court began finding unconstitutional rather obvious infringements on basic rights to vote. The white primaries, through which southern whites excluded blacks from the only meaningful participation in electoral politics, were struck down. ${ }^{18}$

17. Lerone Bennett, Jr., Before the Mayflower: A History of Black America 369-70 (5th ed., Penguin Books 1984) (1962).

18. Terry v. Adams, 345 U.S. 461 (1953) (holding that a selection of candidates by a "private" allwhite Jaybird primary whose selections then appeared on the Democratic Party primary was a violation of the Fifteenth Amendment); Smith v. Allwright, 321 U.S. 649 (1944) (recognizing that party nominating candidates deemed agency of the state and exclusion of blacks violated their rights under the Fourteenth and Fifteenth Amendments). 
Resisting whites saw these decisions as peremptory revocation of policies they considered permanent. Yet, while deeming themselves the prime motivations for policies of white preference, whites could no longer use the law to require continued enforcement of these preferences. Thus, whites too became fortuitous beneficiaries of racial policies adopted and abandoned for reasons beyond race. The up and down history of affirmative action in the courts is an excellent contemporary example of how this process works.

What are the motivations, the invisible forces that move both individuals and groups to function so predictably across time and a wide variety of conditions that ensure a perpetual subordinate role for all but a fortunate few of those Americans who are not white? The symbols change and the society sometimes even accepts standards like "equal opportunity" that civil rights advocates have urged on it, but in practice, somehow such standards serve to strengthen, not weaken, the subordinate status of African-Americans. And to our horror, that status is stabilized, rather than alleviated, by the movement up through the class ranks of the precious few blacks, including myself, who too quickly are cited as proof both that racism is no more and that the indolence of blacks, rather than continuing racial injustice, explain the socio-economic gaps that separate the races.

For many years now, I have been disturbing friends and critics by expressing the view, based on history and personal experience, that racism is permanent in this country. ${ }^{19}$ My statement may seem more provocative than instructive. Here, I want to elaborate on it by asserting that it is racism that underlies the paradox of a nation built on the combination of free-market economy and popular democracy.

There are many factors that enable the maintenance of this paradox, but an ideology of racism in the United States and some other developed countries has been a powerful force, fracturing the "lower class" and inducing large numbers of the less well-off majority to think, vote, and act in defiance of what might be expected to be their rational economic self-interest. ${ }^{20}$ Racism (and the creation of a large racial underclass), has arguably made poor and working-class whites feel better about their relative plight, giving them a consoling sense of superiority and status vis-à-vis African Americans,

19. Derrick Bell, Faces at the Bottom of the Well: The Permanence of Racism (1992).

20. Amy L. Chua, The Paradox of Free Market Democracy: Rethinking Development Policy, 41 HARV. INT'L L.J. 287 (2000). 
Hispanic Americans, and other groups of color perceived (in many senses correctly) as "the sediment of the American stratificational order." 21

The historic serves as a guide to understanding the present. ${ }^{22}$ The ideology of whiteness continues to oppress whites as well as blacks. Now, as throughout the American experience, it is employed to make whites settle for despair in politics and anguish in the daily grind of life. Somehow, they link the fact that a majority of America's population is white and most power is held by whites with a sense that, as whites, they are privileged and entitled to preference over people of color. Over time, these views have solidified into a kind of property - a property in whiteness. The law recognizes and protects this property right based on color like any other property.

Understanding should lead to new approaches rather than despair. Racial justice advocates, rather than await the accidental benefits of policy-making, can forge fortuity. Many blacks already understand and incorporate this approach in interchanges with whites on the job, and in their commercial and community dealings. My parents were typical of many who drilled into their children at an early age that because you are black, you have to be twice as good to get half as much. Unspoken in that advice is that whites are presumed competent until they prove the contrary. Blacks are assumed to be mediocre, and certainly no intellectual match for smart whites, until their skills and accomplishments gain them an often reluctant acceptance. Success for the black person requires effective functioning achieved with the knowledge that their work will not be recognized or rewarded to the same degree as a white person doing the same thing. A black person may be a fortuitous beneficiary, but it is usually necessary to push the dynamics of fortuity hard to get into that status.

Those who took part in the sit-ins were forging fortuity. By their nonviolent protests, they dramatized the justice of their cause and overcame traditional laws of trespass and breach of the peace. Their leaders were able to think and plan within a context of "what is" (the existing problem) rather than simply rely on the abstract concept of equality. The sit-ins taught us that a great many whites would not maintain discriminatory policies if the cost is too high. Employing tactics based on this knowledge will lift the sights, providing a bird's eye view of discriminatory situations and how best to address them. From this broadened perspective on events and problems, we

21. Id. at 306 (citing Melvin L. Oviver \& Thomas M. Shapiro, Black Wealth/White Wealth: A New Perspective on Racial Inequality 5 (1995)).

22. David R. Roediger, The Wages of Whiteness: Race and the Making of the American WORKING Class (1991). 
can recognize, understand, and thus be better able to cope with the various stages of racial subordination.

Significantly, there are educators, some in public institutions, many in private schools, that are forging fortuity by structuring their teaching plans to meet the needs of the students they serve. The results are often impressive. While not excluding whites, their priority is no longer integration, but on implementing teaching techniques that overcome the barriers to motivation and learning that serve as obstacles for the students who are economically disadvantaged and racially subordinated. Those who organize and teach in these schools deserve our commendations and continuing support on the 50th anniversary of the Brown decision.

We must recognize and acknowledge (at least to ourselves) that our actions are unlikely to lead to transcendent change and, despite our best efforts, may be of more help to the system we despise than to the victims of that system whom we are trying to help. Then, that realization, and the dedication that is nurtured, rather than discouraged, based on that realization, can lead to policy positions and campaigns that are less likely to worsen conditions for those we are trying to help, and more likely to remind the powers that be that out there are persons like us who are not on their side and who are determined to stand in their way. But beyond that, continued struggle can bring about unexpected benefits and gains that, in themselves, justify continued endeavor.

And so the battle continues, but the necessary commitment must be combined with tactical savvy that is the survival dividend for those locked in subordinate status. That status provides the potential to better recognize, understand, and respond to, recurring aspects of our condition. We can both think and plan within a context of what is, rather than idealism. We know, for example, that a great many whites will not maintain discriminatory policies, or even beliefs, if the cost is too high or if the benefits of easing discriminatory policies are sufficiently obvious. Designing strategies based on this knowledge will lift the sights, providing a bird's eye view of discriminatory situations and how best to address them.

I tried to illustrate this approach in my story, "The Space Traders." ${ }^{23}$ There, aliens land in America and offer the Nation enticing forms of wealth, asking in return that they be able to take all black Americans away to destinations unknown. Blacks are appalled, but the obvious benefits to whites

23. Derrick Bell, The Space Traders, in Faces at the Bottom of the Well: The Permanence OF RACISM 158 (1992). 
lead government leaders and much of the citizenry to support the trade, and they are determined to call a national referendum to decide the question.

A black conservative, Gleason Golightly, recognizing that whites often cast votes that reflect their racial views, tries to convince black leaders that their only hope is to spread the word that the Space Traders are taking blacks to an ideal place, literally a land of milk and honey. He argues that because whites believe they are entitled to priority over blacks for all good things, they will vote against the trade. He tells the leaders:

Although you are planning to litigate against the trade on the grounds that it is illegal discrimination to limit it to black people, mark my words, our "milk and honey story will inspire whites to institute such litigation on the grounds that limiting the Space Traders" offer to black people is unconstitutional discrimination against whites! $!^{24}$

The civil rights leaders reject the plan as dishonest and simply a conservative trick. Left alone, Golightly is crushed by his failure to get them to recognize what he had long known: "that without power, a people must use cunning and guile ... based on superior understanding of [the] situation." 25 This, he suggests, is a form of potent power. Just as the Brown decision's major contribution to the freedom struggle was the Nation's response to the violent resistance of its opponents, so we who were its intended beneficiaries can learn from the myriad ways in which the relief we deserved was withheld. Brown, in retrospect, was a serious disappointment, but if we can learn the lessons it did not intend to teach, it will not go down as a defeat.

24. Id. at 176 .

25. Id. at 178 . 